\title{
Vörösiszappal szennyezett talajok kémhatása és sav-bázis pufferoló képessége barnaszéntartalmú talajjavító anyag alkalmazását követően
}

\author{
FILEP Tibor, RÉKÁSI Márk és MAKÓ András
}

MTA Agrártudományi Kutatóközpont, Talajtani és Agrokémiai Intézet, Budapest

\section{Bevezetés}

2010. október 4-én, Ajkán a MAL Zrt. X. sz. vörösiszap-tározókazetta gátja átszakadt, és ennek következtében $700000 \mathrm{~m}^{3}$ vörösiszap és lúgos víz elegye ömlött a Torna patakba és a környező települések (Kolontár, Devecser, Somlóvásárhely), illetve az ezeket övező mezőgazdasági területek talajaira. A szennyezett területek nagysága elérte a 800 ha-t. A kiömlő vörösiszap a talajfelszínt átlagosan 5-10 cmes (domborzattól függően $3-45 \mathrm{~cm}$ ) rétegben borította be.

A vörösiszap kémiai tulajdonságai közül leginkább erősen lúgos kémhatása ( $\mathrm{pH}$ 10-11) és rendkívül nagy Na-ion koncentrációja $\left(101,4 \pm 81,6 \mathrm{mmol} \mathrm{Na} \cdot \mathrm{L}^{-1}\right)$ kiemelendő (MAKÓ et al., 2014). Ez utóbbi következménye az is, hogy az kolloidok felületén jelentős mennyiségü Na-ion adszorbeálódik (SAR: 307,2 $\pm 233,1$; ESP: $68,9 \pm 19,6 \%$ ). A magas $\mathrm{pH}-$ nak jelentős szerepe van a talajkolloidok töltésviszonyainak megváltozásában és ennek következtében az adszorpciós és ioncsere folyamatok eltolódásában, illetve a szerves molekulák oldhatóságának növekedésében (FILEP, 1988; SPOSITO, 2008). A talajok vörösiszappal való szennyezésének további következménye a talajkolloidok diszperziója, majd a szerkezet leromlása (GUYONNET et al., 2005; TOURNASSAT et al., 2011). A fentebb felsorolt kémiai változások és egyéb káros hatások miatt (pl. a toxikus elemek mobilizációja), a vörösiszappal szennyezett területek kármentesítése, valamint a szennyezés és a kármentesítés hatásainak vizsgálata kiemelt fontosságú. Az utóbbi években számos publikáció jelent meg, amelyben vizsgálták pl. a vörösiszap toxikus elemeinek mobilitását vagy a vörösiszap hatását a talaj mikrobiológiai paramétereire (ANTON et al., 2012; GRUIZ et al, 2012; RÉKÁSI et al., 2013).

A 2010-es Ajkai iszapömlés után a negatív hatások csökkentése és eliminálása érdekében többféle kárelhárítási módszert is kipróbáltak a szennyezett területeken. $\mathrm{Az}$ iszappal jelentős mértékben szennyezett területeken először talajcserét alkalmaztak. A kevésbé szennyezett területeken az iszapot beszántották a talajba, hogy csökkentsék a kiszáradó vörösiszap porként való terjedését. A lúgosság és a magas

Postai cím: FILEP TIBOR, MTA ATK Talajtani és Agrokémiai Intézet. 1022 Budapest, Herman Ottó út 15. E-mail: filept@rissac.hu 
- bár biológailag nem felvehető - elemkoncentráció csökkentésére különféle anyagokkal illetve eljárásokkal kísérleteztek: gipsz kiszórásával, fitoremediációval, savanyító hatású műtrágyák alkalmazásával, alginit, gilisztahumusz és komposzt felhasználásával, illetve szerves trágya, tőzeg, finomra darált növényi maradványok és a DUDARIT ${ }^{\mathfrak{B}}$ talajba juttatásával próbálták enyhíteni a vörösiszap káros hatásait.

A dudari barnaszénböl készült DUDARIT ${ }^{\circledR}$ fantázianéven forgalmazott terméket Magyarországon a DUSZÉN Kft. gyártja 1998 óta (MGSzH, 2009). Ugyanerre az anyagra HUMINIT ${ }^{\mathcal{O}}$ néven kapott forgalomba hozatali engedélyt a Humin Project Környezetvédelmi és Szolgáltató Kft. 2009-ben. A gyártástechnológia alapötlete az volt, hogy a huminsavak K-humáttá alakításához a költséges $\mathrm{KOH}$ helyett fahamut alkalmaznak, amelynek nagy K-oxid tartalma az oldódás során hidroxiddá alakul, így biztosítva a K-humát képződést. A kereskedelmi forgalomban létezik még a DUDARIT NPK ${ }^{\circledR}$ nevü készítmény (mely a barnaszénen és a fahamun kívül csak nitrogén-, foszfor-, kálium mütrágyát tartalmaz), illetve a DUDARIT NPK Plusz ${ }^{\mathbb{R}}$ és a HUMINIT NPK Plusz ${ }^{\circledR}$ (mely készítményekben van magnézium-, vas-, cinkés mangán-kiegészítés; DUSZÉN, 2012).

A DUDARIT ${ }^{\circledR}$ hatását a talaj, valamint a növény tápanyagtartalmára FARKAS (2010) vizsgálta. Megállapította, hogy a kezelés hatására a talajok kémhatása nem változott lényegesen, a kontroll minta kémhatása $(\mathrm{pH}(\mathrm{KCl}) 7,15)$ alig csökkent $(\mathrm{pH}(\mathrm{KCl})$ 7,12). Annak ellenére, hogy az Ajkai katasztrófát követően a vörösiszappal szennyezett területek a kárenyhítésére több helyszínen is alkalmazták a DUDARIT ${ }^{\circledR}$-ot, az anyag kémiai hatásainak elemzése mindezidáig elmaradt dolgozatunkban ezt kívántuk pótolni. A jelen közleményünkben bemutatandó vizsgálatainknak célja az volt, hogy laboratóriumi modellkísérletben (1) tanulmányozzuk a DUDARIT ${ }^{\circledR}$ hatását a vörösiszappal szennyezett talaj pH-jára, (2) kvantifikáljuk a DUDARIT ${ }^{\circledR}$ sav-bázis pufferoló hatását, illetve (3) tisztázzuk azokat a mechanizmusokat, melyek az esetleges pufferhatás közvetlen okozói lehetnek.

\section{Anyag és Módszer}

\section{Laboratóriumi modellkisérlet}

A modell oszlopkísérlethez használt talajminta egy Kolontár és Devecser település között elhelyezkedő, vörösiszappal nem szennyezett szántóföldi területen feltárt talajszelvény felső $(0-30 \mathrm{~cm})$ „A” genetikai szintjéből származott (É: 475'55.60"; $\mathrm{K}$ : 17²8'12.96"; tszfm: $182 \mathrm{~m}$ ). A talaj semleges kémhatású, kis $\mathrm{CaCO}_{3}$ - és közepes humusztartalmú, homok-homokos vályog fizikai féleségü, kavicsos humuszos öntéstalaj (WRB: Eutric Fluvisols Arenic). A talaj jellemzői a következőek voltak: $\mathrm{pH}\left(\mathrm{H}_{2} \mathrm{O}\right)$ 6,76; $\mathrm{pH}(\mathrm{KCl}) 6,45 ; \mathrm{CaCO}_{3}$ tartalom: 1,29\%; humusztartalom: 2,17\%; Térték: $9,33 \mathrm{cmol}_{\mathrm{c}} \cdot \mathrm{kg}^{-1}$. A talajmintát légszáraz állapotig szárítottuk, eltávolítottuk kavicstartalmát, ledaráltuk, 2 mm-es szitán átszitáltuk, majd az eredeti kavicstartalommal összekeverve $10 \mathrm{~cm}$ átméröjü és $30 \mathrm{~cm}$ magas PVC csövekbe töltöttük 28 , 25 és $20 \mathrm{~cm}$ talaj-vastagságban. Az oszlopok alját polietilén textillel zártuk le (1. ábra). 


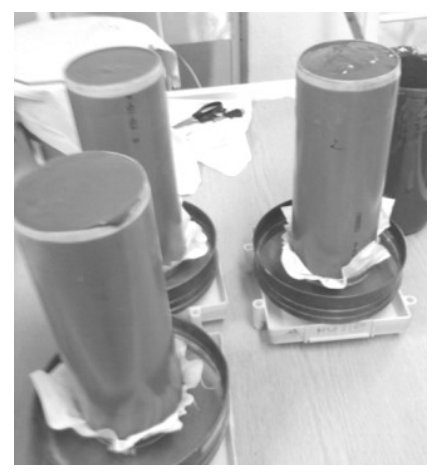

1. ábra

A modellkísérlet talajoszlopai

A talajoszlopokra 2, 5 és $10 \mathrm{~cm}$-nyi vörösiszapot rétegeztünk (a vörösiszap nedvességtartalma $38 \mathrm{~m} / \mathrm{m} \%$ volt). A vörösiszap kezelések maximuma $(10 \mathrm{~cm})$ a ráhordás maximális vastagságát szimulálta. Az ennél vastagabb ráhordást a gyakorlatban már talajcserével semlegesítették. Kísérletünkben azt a helyzetet modelleztük, amikor a talaj $0,2,5$ és $10 \mathrm{~cm}$ vastag vörösiszap borítást kapott, amelyet utána $30 \mathrm{~cm}$ mélyen megforgattak.

Az oszlopokat szobahőmérsékleten - a légszáraz nedvességtartalom elérésig szárítottuk, majd a vörösiszappal kezelt talajt dörzsmozsárban homogenizáltuk és 2 mm-es szitán ismét átszitáltuk. A négy kezeléshez (három kezelt talaj és a kontroll) különböző mennyiségü $\left(0,5,10\right.$ és $50 \mathrm{t} \cdot \mathrm{ha}^{-1}$ javítóanyagnak megfelelö) DUDARIT $^{\mathbb{B}}$-ot adtunk.

\section{1. táblázat}

A begyüjtött vörösiszap-minta kémhatása, valamint összes és vízoldható elemtartalma (ANTON et al., 2012)

\begin{tabular}{|c|c|c|c|c|c|c|c|c|c|c|c|c|c|c|}
\hline \multicolumn{2}{|c|}{$\mathrm{pH}$} & \multirow{2}{*}{$\begin{array}{l}(1) \\
\text { Frakció }\end{array}$} & \multicolumn{12}{|c|}{$\begin{array}{c}\text { (2) } \\
\text { Elemtartalom, mg } \cdot \mathrm{kg} \text { száraz tömeg }{ }^{-1}\end{array}$} \\
\hline $\mathrm{H}_{2} \mathrm{O}$ & $\mathrm{KCl}$ & & $\mathrm{Al}$ & As & $\mathrm{Cd}$ & $\mathrm{Co}$ & $\mathrm{Cr}$ & $\mathrm{Cu}$ & Mo & $\mathrm{Na}$ & $\mathrm{Ni}$ & $\mathrm{Pb}$ & $\mathrm{Se}$ & $\mathrm{Zn}$ \\
\hline \multirow{2}{*}{10,21} & \multirow{2}{*}{9,86} & a) Összes & 51470 & 32,1 & 1,17 & 40,3 & 396 & 34,5 & 3,00 & 32918 & 193 & 117 & $<\mathrm{kh}$ & 107 \\
\hline & & b) Víold. & 167 & 2,52 & 0,01 & 0,16 & 1,27 & 1,63 & 5,35 & 3680 & 0,77 & 0,43 & $<\mathrm{kh}$ & 0,61 \\
\hline
\end{tabular}

Megjegyzés: $\mathrm{kh}$ a kimutatási határ. A kh a szelén esetében $0,6 \mathrm{mg} \cdot \mathrm{kg}^{-1}$

\section{2. táblázat}

A DUDARIT $^{\circledR}$ alapparaméterei és elemtartalma (FARKAS, 2010)

\begin{tabular}{|c|c|c|c|c|c|c|c|}
\hline \multirow{3}{*}{$\begin{array}{c}\mathrm{pH} \\
\left(\mathrm{H}_{2} \mathrm{O}\right)\end{array}$} & \multirow{2}{*}{$\begin{array}{c}(1) \\
\text { Szervesanyag- } \\
\text { tartalom }\end{array}$} & \multirow{2}{*}{\begin{tabular}{|c|} 
(2) \\
Összes só- \\
tartalom
\end{tabular}} & \multicolumn{5}{|c|}{$\begin{array}{c}3) \\
\text { Elemtartalom }\end{array}$} \\
\hline & & & $\mathrm{N}_{\text {Össz }}$ & $\mathrm{P}_{\text {Össz }}\left(\mathrm{P}_{2} \mathrm{O}_{5}\right)$ & $\mathrm{K}_{\text {Össz }}\left(\mathrm{K}_{2} \mathrm{O}\right)$ & $\mathrm{Ca}$ & $\mathrm{Mg}$ \\
\hline & $\%$ & $\%$ & \multicolumn{5}{|c|}{$\%$} \\
\hline 8,52 & 52,26 & 3,21 & 5,76 & 6,89 & 5,78 & 8,87 & 0,87 \\
\hline
\end{tabular}


A kísérletekben felhasznált vörösiszap és a DUDARIT ${ }^{\circledR}$ alapparamétereit, illetve elemtartalmát ANTON és munkatársai (2012) és FARKAS (2010) nyomán az 1. és 2. táblázatban mutatjuk be.

\section{Talajvizsgálatok}

A fizikai és kémiai vizsgálatokhoz előkészített (légszáraz, darált: $<2 \mathrm{~mm}$ és homogenizált) vörösiszap és talajminták kémhatását a hazai szabvány szerint (MSz 08-0206/2:1978) mértük. A szervesanyag-tartalmat Tyurin-féle módszerrel (MSz 08-0452:1980), a $\mathrm{CaCO}_{3}$-tartalmat a Scheibler-módszerrel (MSz 08-0206/2:1978), a kationcserélő kapacitást (T-érték) pedig a módosított Mehlich-módszerrel (MSZ 08-0215:1978) határoztuk meg.

A minták összes elemtartalmát ICP-AES készülékkel mértük mikrohullámú, királyvizes feltárás után (RÉKÁSI \& FILEP, 2006).

\section{A sav-bázis pufferkapacitás mérése}

A talaj sav-bázis pufferoló képességét (pufferkapacitását) a JENSEN (1924), illetve a CHRISTENSEN és JENSEN (1926) által javasolt eljárásnak megfelelően határoztuk meg. A porított, légszáraz talajból 10-10 g-ot mérünk $300 \mathrm{~cm}^{3}$-es Erlenmeyer lombikokba. A bemért talajokhoz növekvő mennyiségü $0,01 \mathrm{~mol} \cdot \mathrm{dm}^{-3}$-es $\mathrm{Ca}(\mathrm{OH})_{2}$, illetve $0,1 \mathrm{~mol} \cdot \mathrm{dm}^{-3}$-es $\mathrm{HCl}$-t adtunk; a hozzáadott $\mathrm{H}^{+}$vagy $\mathrm{OH}^{-}$-ion mennyisége ennek megfelelően $0,2,6,8,10$ és $12 \mathrm{cmol}_{\mathrm{c}} \cdot \mathrm{kg}^{-1}$ volt. A lombikokat ezután desztillált vízzel jelig töltöttük és három napig állni hagytuk. Ezt követően mértük a szuszpenziók egyensúlyi pH-ját, majd a pH-értékeket ábrázoltuk a hozzáadott bázis, illetve sav mg-egyenérték függvényében (1 kg talajra vonatkoztatva).

A talaj pH-jának és sav-bázis pufferoló képességének meghatározásánál nem állítottunk be ismétlést, mert a pH statisztikai elemzésének eredménye általában erősen kétséges - annak logaritmikus jellege miatt.

\section{Eredmények}

\section{A DUDARIT $T^{\circledR}$ alkalmazásának hatása a talaj pH-jára}

A DUDARIT ${ }^{\circledR}$ kezelések hatását a talaj pH-jára a 3. táblázatban foglaltuk össze.

Az iszap-szennyezés hatása egyértelmü: növekedésével jelentősen nő a talajok pH-ja, a semleges közeli pH 7 értékről (kontroll-talaj) az egészen lúgos kémhatású pH 9,5 körüli értékre (vörösiszappal szennyezett talajok).

A DUDARIT $^{\circledR}$ adagolásának nincs egyértelmű következménye a talaj kémhatására. Az $5 \mathrm{~cm}$ vastag iszappal kezelt talaj kémhatása 8,80-ról 8,46-ra, a $10 \mathrm{~cm}$ iszapot tartalmazó minták pH-ja pedig 9,49-ről 9,33-ra csökkent a DUDARIT ${ }^{\circledR}$ kezelések hatására. Ezek a változások azonban nem szignifikánsak. A kontrollminták esetén is - amelyek nem kaptak vörösiszap-kezelést - kimutatható enyhe, de egyértelmúen trendszerü pH-változás: a talaj pH-ja 7,14-ről 6,89-re csökkent. 
3. táblázat

A DUDARIT ${ }^{\mathbb{B}}$-kezelés hatása a vizsgált talajok $\mathrm{pH}\left(\mathrm{H}_{2} \mathrm{O}\right)$-értékeire

\begin{tabular}{|c|c|c|c|c|c|}
\hline \multirow{2}{*}{$\begin{array}{c}(1) \\
\text { Iszapréteg }\end{array}$} & \multicolumn{5}{|c|}{ DUDARIT $^{\circledR}$} \\
\hline \multirow{2}{*}{$\mathrm{cm}$} & 0 & 5 & 10 & 50 & Átlag \\
\cline { 2 - 6 } & 7,14 & 7,03 & 6,78 & 6,89 & 6,96 \\
0 & 8,01 & 8,15 & 8,12 & 7,90 & 8,04 \\
2 & 8,80 & 8,58 & 8,61 & 8,46 & 8,61 \\
5 & 9,49 & 9,64 & 9,57 & 9,33 & 9,51 \\
10 & 8,36 & 8,35 & 8,27 & 8,14 & \\
a) Átlag & \multicolumn{5}{|c}{} \\
\hline
\end{tabular}

\section{A talaj sav-bázis pufferoló képességének értékelése}

A talajok pufferkapacitását úgy jellemeztük, hogy az adagolt $\mathrm{H}^{+}$illetve $\mathrm{OH}^{-}$ mennyiségének függvényében ábrázoltuk az egyensúlyi pH-értékeket. Az így kapott pontokra lineáris függvényt illesztettünk (2. ábra). Az egyenes meredeksége - annak abszolút értéke - mutatja meg azt, hogy egységnyi $\mathrm{H}^{+}-$vagy $\mathrm{OH}^{-}-$változás mennyivel változtatja meg a rendszer $\mathrm{pH}$-ját. Minél kisebb ez az érték, annál jobban pufferolja a talaj a sav- illetve lúg-hatásokat.

MAGDOFF és BARTLETT (1985) a titrálási görbe középső, meredek szakaszára (pH 4-9) illesztettek regressziós egyenest. Vizsgálatunkban ehhez hasonló $\mathrm{pH}-$ intervallumban ( $\mathrm{pH} 4-10)$ jellemeztük a sav-bázis pufferoló képességet.

Annak ellenére, hogy a számos vizsgálat kimutatta a szerves anyagok jelentős pufferoló képességét, jelen kísérletünkben a DUDARIT ${ }^{\circledR}$ nem növelte szignifikánsan a talajok sav-bázis pufferoló képességét (4. táblázat).

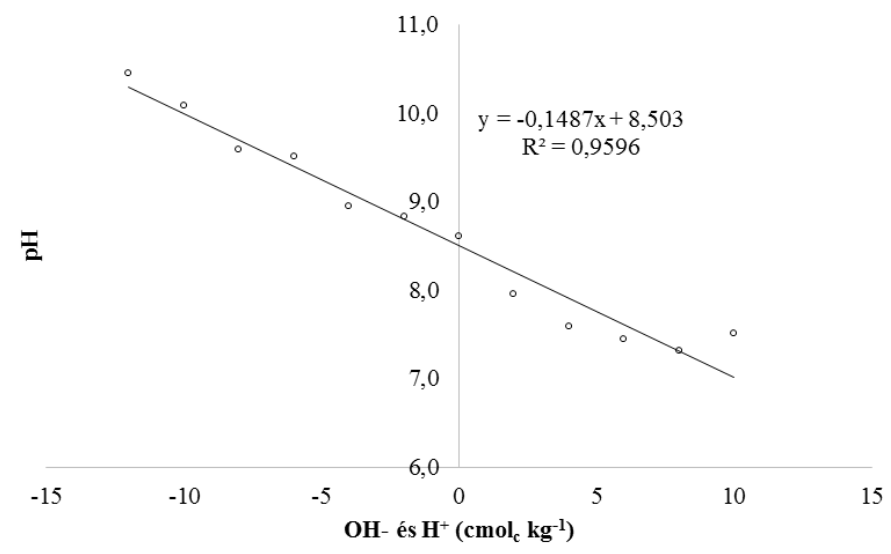

\section{2. ábra}

Az $5 \mathrm{~cm}$-es iszappal szennyezett és $10 \mathrm{t} \cdot \mathrm{ha}^{-1}$ DUDARIT $^{\circledR}$-tal kezelt talaj puffergörbéje 
4. táblázat

A sav-bázis pufferoló képesség változása az iszap-terhelés és a DUDARIT ${ }^{\circledR}$ adagolással

\begin{tabular}{|c|c|c|c|c|c|}
\hline \multirow{2}{*}{$\begin{array}{c}\text { (1) } \\
\text { Iszapréteg }\end{array}$} & \multicolumn{5}{|c|}{ DUDARIT $^{\circledR}$} \\
\hline \multirow{2}{*}{$\mathrm{cm}$} & \multicolumn{5}{|c|}{$\mathrm{t}^{-1}$} \\
\cline { 2 - 6 } & 0 & 5 & 10 & 50 & Átlag \\
\hline 0 & 0,328 & 0,336 & 0,313 & 0,313 & 0,322 \\
2 & 0,129 & 0,143 & 0,143 & 0,128 & 0,135 \\
5 & 0,138 & 0,150 & 0,149 & 0,123 & 0,140 \\
10 & 0,131 & 0,116 & 0,120 & 0,114 & 0,120 \\
a) Átlag & 0,181 & 0,186 & 0,181 & 0,169 & \\
\hline
\end{tabular}

A puffergörbe meredekségének trendszerű csökkenését tapasztaltuk a DUDARIT $^{\circledR}$ alkalmazását követően, ami a pufferkapacitás növekedését jelenti. Ez a csökkenés azonban oly csekély, hogy az sem mondható ki egyértelműen, hogy az 50 $\mathrm{t} \cdot \mathrm{ha}^{-1}$ DUDARIT $^{\circledR}$ növelte a talaj sav-bázis pufferkapacitását. A pufferkapacitás növekedése csupán az iszappal kezelt és az iszappal kezeletlen talajok között szignifikáns. Ez akkor érthető meg, ha megvizsgáljuk az iszappal kezeletlen talajok puffergörbéjét: példaként az $5 \mathrm{t} \cdot \mathrm{ha}^{-1}$ DUDARIT $^{\circledR}$-tal kezelt talaj puffergörbéjét mutatjuk be (3. ábra).

A talaj pufferképessége viszonylag csekély volt. A szuszpenzió a savterhelések hatására 3,33, míg a lúgterhelésre 8,98-as pH-t ért el.

A vörösiszap hozzáadásával olyan pufferoló közeget juttattunk a talajba, amely a benne lévő $\mathrm{NaOH}$ miatt jelentős mértékben csökkentette a sav-hatásokat. A puffergörbe feljebb csúszott, meredeksége csökkent, hiszen a $\mathrm{NaOH}$ a savat semlegesítette, a lúgos tartományban pedig jelenlétével pufferolta a rendszert.

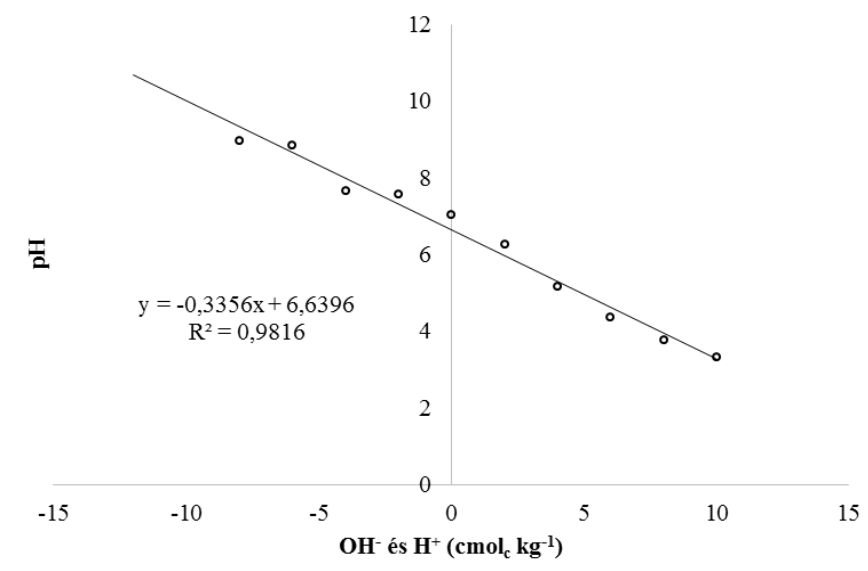

3. ábra

A vörösiszappal nem szennyezett és $5 \mathrm{t} \cdot \mathrm{ha}^{-1}$ DUDARIT $^{\mathbb{B}}$-tal kezelt talaj puffergörbéje 
Minél több vörösiszap volt a talajon, a talaj $\mathrm{pH}$-értéke annál nagyobb volt. A pH logaritmikus természetéből fakadóan a nagyobb $\mathrm{pH}$-értéken ugyanakkora $\mathrm{pH}$ változáshoz több lúg hozzáadása szükséges - azaz minél lúgosabb a talaj, annál nagyobb a lúgokkal szemben a pufferképessége.

\section{Szerves pufferrendszerek mechanizmusainak értékelése a DUDARIT ${ }^{\circledR}$ adagolásakor}

A talajban lévő szerves anyag és az azt alkotó molekulák, legyenek kis molekulatömegüek, avagy makromolekulák, reaktív funkciós csoportjaik révén képesek azokat a hatásokat tompítani, amelyek egyrészt a talaj természetes dinamikájával függenek össze, másrészt külső, akár emberi behatásra jelennek meg. A szerves anyag pufferrendszerét alkotó funkciós csoportok savas karakterisztikája határozza meg, hogy azok mely pH-tartományban hatásosak, mint sav-bázis pufferrendszer (STEVENSON, 1994).

A karboxil-csoportok egyensúlyi állandójának negatív logaritmusát $\left(\mathrm{pK}_{\mathrm{a}}\right) 3,5-$ 6,4 között határozták meg különböző rendszerekben (eltérő szerkezetủ humuszmolekulákon), míg a fenolos-OH pK $\mathrm{a}_{\mathrm{a}}$-ja 6,9-9,0 közötti (CAMPITELLI et al., 2006). A $\mathrm{pK}_{\mathrm{a}}$-értékek adott értéktartományon belüli szóródása a funkciós csoport molekulán belüli és az egymáshoz, ill. más funkciós csoportokhoz viszonyított helyzetével magyarázható. A karboxil és a fenolos- $\mathrm{OH}$ csoportok aciditása a molekulákban közel azonos (CAMPITELLI et al., 2006), bár talajonként és humusz-frakciónként ez jelentősen módosulhat. A humuszmolekulákban esetlegesen előforduló N-tartalmú funkciós csoportok, különösen az amino-csoport $\mathrm{pK}_{\mathrm{a}}$-értéke 6,8-9,1 körüli (PACE et al., 2009). Ennél a pH-értéknél deprotonálódik az $-\mathrm{NH}_{3}{ }^{+}$csoport. Ezek szerepe azonban a sav-bázis pufferrendszerekben mennyiségüknél fogva is kisebb.

Ahhoz, hogy értékelni tudjuk a DUDARIT ${ }^{\circledR}$ sav-bázis pufferoló képességét, azt kell megvizsgálnunk, hogy az adott pH-értéken ezek a funkciós csoportok milyen mértékben protonáltak vagy deprotonáltak. A DUDARIT ${ }^{\circledR}$ kémhatása enyhén lúgos $(\mathrm{pH}: 8,52)\left(2\right.$. táblázat), a fahamuban található nagy mennyiségü $\mathrm{K}_{2} \mathrm{O}$ és $\mathrm{CaO}$ miatt, amelyek oldódása $\mathrm{KOH}$-ot és $\mathrm{Ca}(\mathrm{OH})_{2}$-ot eredményez, közel 14-es pH-értékkel (FARKAS, 2010). A DUDARIT ${ }^{\circledR}$ szerves molekulái, sőt a talaj humuszmolekulái pH: 8-9-érték közelében jelentős negatív töltésủek (GONDAR et al., 2005; PLAZA et al., 2006), a karboxil-csoportok teljes disszociációja és a fenolos- és enolos-OH csoportok részleges deprotonálódása következtében. Ez a folyamat a szerves molekulák oldódását jelentősen elősegíti, hiszen a töltés illetve a töltéssürüség növekedése egyre hidrofilebbé teszi azokat (TOMBÁCZ \& RiCE, 1999). Ennek következtében jelentős mennyiségü huminsav oldódhat ki a barnaszénből, amit az ionerősség növekedése is segít (CHRISTL \& KRETZSCHMAR, 2001).

Azokon a $\mathrm{pH}$-értékeken, amelyek megközelítőleg azonosak vagy nagyobbak, mint a gyenge savcsoport $\mathrm{pK}_{\mathrm{a}}$ értéke $\left(\mathrm{pK}_{\mathrm{a}} \approx \mathrm{pH}\right.$ vagy $\left.\mathrm{pK}_{\mathrm{a}}<\mathrm{pH}\right)$ nem várható érdemi pH-korrekció (RitchIE \& DOLLING, 1985). Ennek okán kétséges, hogy a DUDARIT $^{\circledR}$ közvetlen és azonnali pufferoló hatást fejthet ki az erősen lúgos talajra, mint ahogyan ezt vizsgálataink meg is erösítették. Figyelembe kell vennünk továbbá azt is, hogy a DUDARIT ${ }^{\circledR}$ - a benne lévő fahamu miatt -, jelentős mennyiségben tartalmaz kationokat $\left(\mathrm{K}^{+}, \mathrm{Ca}^{2+}\right)$, melyek a talajoldatba jutva részt vesznek a talaj 
kémhatását módosító határfelületi reakciókban (pl. a $\mathrm{Ca}^{2+}-\mathrm{H}^{+}$ioncsere az ásványi kolloidok felületén). Nagy valószínüséggel ez okozta a vizsgált talajok általunk tapasztalt kismértékü savanyodását. Ez a fajta ioncsere, melyet talán helyesebb lenne komplexképződésnek titulálni, a szerves anyagoknál azért nem játszik szerepet ezen a pH-n, mert - mint azt kimutattuk -, a gyenge sav karakterü funkciós csoportok disszociált formában vannak. Bár azonnali hatás nem mutatható ki, nem jelenthetjük ki azt, hogy a DUDARIT ${ }^{\circledR}$-kezelések nem fogják módosítani a talaj kémhatás-viszonyait. A legfontosabb $\mathrm{H}^{+}$és $\mathrm{OH}^{-}$termelö/fogyasztó folyamatok a talaj szerves anyagának transzformációihoz kapcsolhatók (BOLAN et al., 1991).

A szerves anyag szénciklusában keletkező $\mathrm{CO}_{2}$, majd az abból létrejövő szénsav egyértelmüen savanyító hatású, a szerves molekulák savkarakterü csoportjainak oxidálódása $\mathrm{CO}_{2}$-dá éppen ellenkezö hatású, különösen akkor, ha a $\mathrm{CO}_{2}$ a légkörbe távozik (HELYAR, 1976). A N- és S-tartalmú szerves molekulák vagy molekularészek mineralizálódása még inkább megváltoztathatja a közeg $\mathrm{pH}$-ját. Az ammonifikáció (a szerves aminok ammóniává történő transzformációja), a denitrifikáció (a nitrát redukciója $\mathrm{N}_{2}$-é) $\mathrm{OH}^{-}$termelö, míg a nitrifikáció (az ammónia átalakulása nitráttá) egyértelmúen $\mathrm{H}^{+}$termelő folyamat (BOLAN et al., 1991). Ezen folyamatok részben kiegyenlítik egymást (pl. a N-ciklusban). A N-formák arányainak megváltozása azonban - akár növényi felvétel, akár kimosódás következtében -, a $\mathrm{H}^{+}$egyensúly eltolódását eredményezi (VAN BREENEN et al., 1983), melynek hatásaként a talaj kémhatása is megváltozik. Nem kétséges, hogy a talajba juttatott szerves anyag (DUDARIT ${ }^{\mathbb{B}}$ ) hasonló átalakulásokon megy át, hosszabb távon módosítva a talaj kémhatását.

\section{Összefoglalás}

A 2010-es Ajkai vörösiszap-katasztrófa hatásainak csökkentésére több tudományos vizsgálat indult, beleértve azokat is, amelyekben különféle adalékanyagokkal próbálták megszüntetni a szennyezett talaj előnytelen, sőt, káros tulajdonságait. Laboratóriumi modellkísérletet állítottunk be annak tesztelésére, hogy a DUDARIT $^{\circledR}$ márkanevű talajjavító anyag, mely a barnaszénből kioldódó huminsavak által éri el jótékony hatását, milyen mértékben optimalizálja a talaj pH-ját, valamint, hogy mennyiben növeli meg a talajok eredeti sav-bázis pufferoló képességét.

Semleges kémhatású, kis $\mathrm{CaCO}_{3}$-tartalmú, homok-homokos vályog fizikai féleségü, közepes humusztartalmú, humuszos öntéstalaj három iszap-szennyezési szintjén (2, 5 és $10 \mathrm{~cm}$-es borítottság) alkalmaztunk 5,10 és $50 \mathrm{t} \cdot$ ha $^{-1}$ DUDARIT ${ }^{\circledR}$-ot, majd mértük a talaj pH-ját és sav-bázis pufferkapacitását. A talaj egyensúlyi pH-ja kis mértékben, tendenciaszerüen, statisztikailag nem igazolt módon csökkent a növekvő DUDARIT ${ }^{\mathbb{R}}$ adagokkal mindhárom iszap-szennyezési szinten. Az iszapkontroll talajok kémhatása $\left(\mathrm{pH}\left(\mathrm{H}_{2} \mathrm{O}\right)\right)$ 7,14-röl 6,89-re, a maximális, $10 \mathrm{~cm}$ iszappal szennyezett talajon 9,49-röl 9,33-ra, míg az iszap-kezelések átlagában 8,36-ról 8,14-es értékre csökkent. A talajok sav-bázis pufferoló képessége a DUDARIT ${ }^{\mathbb{B}}$ kezelések hatására nem változott szignifikánsan; bár minden iszap-kezelésben nőtt a 
talajok pufferoló képessége a DUDARIT ${ }^{\circledR}$ adagokkal, csak a maximális adag (50 $\mathrm{t} \cdot \mathrm{ha}^{-1}$ ) okozott jól észlelhető növekedést.

A DUDARIT ${ }^{\circledR}$ és vele együtt az igen lúgos kémhatást okozó fahamu, illetve a kioldódó huminsavak alapvetően nem változtatták meg a lúgos kémhatású talajminták kémhatásviszonyait. Ennek alapvető oka az, hogy a huminsavak gyenge savkarakterủ funkciós csoportjai részben vagy teljes egészében disszociált állapotban vannak ezen a talaj és a DUDARIT ${ }^{\circledR} \mathrm{pH}-n$. Azokon a pH-értékeken ugyanis, amelyek megközelítöleg azonosak vagy nagyobbak, mint a gyenge sav csoport $\mathrm{pK}_{\mathrm{a}}$ értéke $\left(\mathrm{pK}_{\mathrm{a}} \approx \mathrm{pH}\right.$ vagy $\left.\mathrm{pK}_{\mathrm{a}}<\mathrm{pH}\right)$ nem várható érdemi $\mathrm{pH}$-korrekció. Bár azonnali hatás nem mutatható ki, nem jelenthetjük ki, hogy a DUDARIT ${ }^{\circledR}$-kezelések nem fogják módosítani a talaj kémhatásviszonyait hosszabb inkubációs periódusban. A szerves anyag mineralizációja $\left(\mathrm{CO}_{2}\right.$ képződés, nitrifikáció, ammonifikáció, denitrifikáció) olyan lényeges hatású $\mathrm{H}^{+}$és $\mathrm{OH}^{-}$forrás a talajban, amely mindenképp a kémhatás módosulásának irányába hat. A DUDARIT ${ }^{\circledR}$ alkalmazása tehát nagy valószínűséggel hosszú távon fejt ki kedvező hatásokat a talaj kémhatására és más tulajdonságaira.

\section{Irodalom}

Anton, A., RÉKÁSI, M., Uzinger, N., SZÉPlÁBI, G. \& ANDRÁs, M., 2012. Modelling the potential effects of the Hungarian red mud disaster on soil properties. Water, Air \& Soil Pollution. 223. 5175-5188.

Bolan, N. S., Hedley, M. J. \& White, R. E., 1991. Processes of soil acidification during nitrogen cycling with emphasis on legume based pastures. Plant and Soil. 134. 53-63.

Campitelli, P. A., Velasco, M. I. \& CepPi, S. B., 2006. Chemical and physicochemical characteristics of humic acids extracted from compost, soil and amended soil. Talanta. 69. 1234-1239.

Christensen, H. R. \& Jensen, S. T., 1926. On the quantitative determination of the lime requirement of the soil. Trans. Cornm. Int. Soc. Soil Sci. A. 94-115.

ChristL, I. \& KRETZSCHMAR, R., 2001. Relating ion binding by fulvic and humic acids to chemical composition and molecular size. 1. Proton binding. Environ. Sci. Technol. 35. 2505-2511.

DUSZÉN BÁNYÁSZATI ÉS SZOLGÁLTATÁSI KFT., 2012. DUDARIT NPK a XXI. sZázad talajjavítója. Agro Napló. január. 47.

FARKAS J., 2010. Növelt hatóanyag tartalmú humusztrágya kifejlesztése, a készítménynyel végzett laboratóriumi és növénytermesztési kísérletek bemutatása. LII. Georgikon Napok, 2010. szeptember 30-október 1, Keszthely. Elektronikus kiadvány. ISBN 978-963-9639-39-3.

FiLEP Gy., 1988. Talajkémia. Akadémia Kiadó. Budapest.

GondAR, R. Lopez, R., Fiol, S., ANTElo, J. M. \& ARCE, F., 2005. Characterization and acid-base properties of fulvic and humic acids isolated from two horizons of an ombrotrophic peat bog. Geoderma. 126. 367-374.

Gruiz, K., Feigl, V., Klebercz, O., Anton, A. \& VAszita, E., 2012. Environmental risk assessment of red mud contaminated land in Hungary. Proceedings CD of 
Geo-Congress 2012, Oakland, March 25-29. 4156-4165. (http://soilutil.hu/en/ node/144)

Guyonnet, D., Gaucher, E., Gaboriau, H., Pons, C.H., Clinard, C., Norrote, V. \& DIDIER, G., 2005. Geosynthetic clay liner interaction with leachate: correlation between permeability, microstructure, and surface chemistry. Journal of Geotechnical and Geoenvironmental Engineering, ASCE. 131. 740-749.

HELYAR, K. R., 1976. Nitrogen cycling and soil acidification. J. Aust. Inst. Agrie. Sci. 42. 217-221.

Jensen, S. T., 1924. Über die Bestimmung der Pufferwirkung des Bodens. Intern. Mitt. Bodenkunde. 14. 112.

Magdoff, F. R. \& Bartlett, R. J., 1985. Soil pH Buffering Revisited. Soil Sci. Soc. Am. J. 49. 145-148.

Makó A., Anton A., CsitÁri G., RÉKÁSi M., Uzinger N., BARnA Gy, SzÉPlÁBi G. \& HERNÁDI H., 2014. Vörösiszappal szennyezett talaj fizikai tulajdonságainak vizsgálata modell oszlopkísérletben. Agrokémia és Talajtan, 63. 203-222.

MGSzH, 2009. HUMINIT-DUDARIT talajkondicionáló készítmény forgalomba hozatali és felhasználási engedélye. Mezőgazdasági Szakigazgatási Hivatal Központ Növény-, Talaj- és Agrárkörnyezet-védelmi Igazgatóság. 02.5/182/3/2009.

Pace, C. N., Grimsley, G. R. \& Scholtz, J. M., 2009. Protein Ionizable Groups: pK Values and Their Contribution to Protein Stability and Solubility. J. Biol. Chem. 284. 13285-13289.

PlazA, C., Hernández, D., FernÁndez, J. M., \& Polo, A., 2006. Long-term effects of amendment with liquid swine manure on proton binding behavior of soil humic substances. Chemosphere. 65. 1321-1329.

RÉKÁSI, M \& FILEP, T., 2006. Effect of microelement loads on the element fractions of soil and plant uptake. Agrokémia és Talajtan. 55. 213-222.

RÉKÁSI, M., Feigl, V., UZInger, N., Gruiz, K., MAKÓ, A., \& ANTON, A., 2013. Effects of leaching from alkaline red mud on soil biota: modelling the conditions after the Hungarian red mud disaster. Chemistry and Ecology. 29. 709-723.

Ritchie, G. S. P. \& Dolling, P. J., 1985. The Role of Organic Matter in Soil Acidification. Australian Journal of Soil Research. 23. 569-576.

Sposito, G., 2008. The Chemistry of Soils. Oxford University Press. New York.

Stevenson, E., 1994. Humus Chemistry, Genesis, Composition, Reactions. Wiley. New York.

TOMBÁcz, E. \& Rice, J. A., 1999. Changes of colloidal state in aqueous systems of humic acids. In: Understanding Humic Substances. Advanced Methods, Properties and Applications. (Eds.: GHABBour E. \& DAvies A. G.) 69-78. The Royal Society of Chemistry. Cambridge.

Tournassat, C., Bizi, M., Braibant, G. \& Crouzet, C., 2011. Influence of montmorillonite tactoid size on $\mathrm{Na}-\mathrm{Ca}$ cation exchange reactions. Journal of Colloid and Interface Science. 364. 443-454.

VAn Breemen, N., Mulder, J. \& Driscoll, C. T., 1983. Acidification and alkalinization of soils. Plant and Soil. 75. 283-308.

Érkezett: 2015. február 27. 


\title{
pH and acid-base buffering capacity of soils contaminated with red mud after treatment with a soil amendment containing brown coal
}

\author{
T. FILEP, M. RÉKÁSI and A. MAKÓ \\ Institute for Soil Science and Agricultural Chemistry, Centre for Agricultural Research, \\ Hungarian Academy of Sciences, Budapest
}

\begin{abstract}
Summary
The red mud disaster that occurred in 2010 resulted in a number of scientific investigations, including those using various soil amendments to ameliorate the unfavourable and in some cases harmful properties of the contaminated soils. A laboratory model experiment was set up to test the extent to which the soil amendment DUDARIT ${ }^{\circledR}$, which exerts a beneficial effect on the soil due to the humic acids released by the brown coal, optimises the soil $\mathrm{pH}$ and enhances the original acid-base buffering capacity of the soil. The soil $\mathrm{pH}$ and the acid-base buffering capacity were measured in an alluvial sandy loam soil with neutral $\mathrm{pH}$, low $\mathrm{CaCO}_{3}$ content and medium humus content, covered by three mud contamination levels $(2,5$ and $10 \mathrm{~cm})$ and treated with 5,10 and 50 $\mathrm{t} \cdot \mathrm{ha}^{-1}$ DUDARIT $^{\circledR}$. Increasing doses of DUDARIT ${ }^{\circledR}$ tended to increase the soil $\mathrm{pH}$ at all the contamination levels, but the differences were not significant. The $\mathrm{pH}$ declined from 7.14 to 6.89 in the control soils and from 9.49 to 9.33 in soils covered with the maximum $(10 \mathrm{~cm})$ red mud layer as the DUDARIT ${ }^{\circledR}$ dose rose, with an average change in $\mathrm{pH}$ over the mud treatments from 8.36 to 8.14 .

The acid-base buffering capacity of the soil did not change significantly in response to the DUDARIT ${ }^{\circledR}$ treatments; although there was an increase in the buffering capacity of the soils at all the contamination levels, only the $50 \mathrm{t} \cdot \mathrm{ha}^{-1}$ dose caused an appreciable increment. In spite of the considerable amount of highly alkaline wood ash and humic acid introduced into the soil with the DUDARIT ${ }^{\circledR}$, the $\mathrm{pH}$ of the alkaline soil samples was only slightly modified. This could be attributed to the fact that the weakly acidic functional groups of the humic acids were partially or totally dissociated at the $\mathrm{pH}$ of the soil/DUDARIT ${ }^{\circledR}$ mixture. At $\mathrm{pH}$ values that are approximately the same or greater than the $\mathrm{pK}_{\mathrm{a}}$ value of the weak acidic groups $\left(\mathrm{pH} \approx \mathrm{pK}_{\mathrm{a}}\right.$ or $\left.\mathrm{pK}_{\mathrm{a}}<\mathrm{pH}\right)$, no substantial change in $\mathrm{pH}$ can be expected. However, the lack of an immediate effect does not necessarily mean that the DUDARIT ${ }^{\circledR}$ doses will not change the acid-base conditions of the soil over a longer incubation period. Since the mineralization of organic matter $\left(\mathrm{CO}_{2}\right.$ efflux, nitrification, ammonification, denitrification) is a significant source of both $\mathrm{H}^{+}$ and $\mathrm{OH}^{-}$in the soil, it can definitely be expected to have a modifying effect on the $\mathrm{pH}$. The use of DUDARIT ${ }^{\circledR}$ is therefore likely to have a long-term positive effect on the $\mathrm{pH}$ and other attributes of the soil.

Table 1. $\mathrm{pH}$ of the red mud samples, and the total and water-soluble element contents (ANTON et al., 2012). (1) Fraction. (2) Element content, $\mathrm{mg} \cdot \mathrm{kg}^{-1}$ dry mass. a) Total, b) Water-soluble. Note: $\mathrm{kh}$ detection limit. In the case of selenium, $\mathrm{kh}=0.6 \mathrm{mg} \cdot \mathrm{kg}^{-1}$.

Table 2. Basic parameters and element content of DUDARIT ${ }^{\circledR}$ (FARKAS, 2010). (1) Organic matter, \%. (2) Total salt content, \%. (3) Element content, $\mathrm{mg} \cdot \mathrm{kg}^{-1}$ dry mass.
\end{abstract}


Table 3. Effect of DUDARIT ${ }^{\circledR}$ treatment on the $\mathrm{pH}\left(\mathrm{H}_{2} \mathrm{O}\right)$ of the tested soils. (1) Mud layer. a) Mean.

Table 4. Changes in the acid-base buffering capacity as a function of mud contamination and DUDARIT ${ }^{\circledR}$ application. (1) Mud layer. a) Mean.

Figure 1. Soil columns in the model experiment.

Figure 2. Buffering curve of a soil contaminated with $5 \mathrm{~cm}$ mud and treated with $10 \mathrm{t}^{\cdot} \mathrm{ha}^{-1}$ DUDARIT $^{\circledR}$.

Figure 3. Buffering curve of a soil not contaminated with red mud and treated with $5 \mathrm{t} \cdot \mathrm{ha}^{-1}$ DUDARIT $^{\circledR}$. 